\title{
The Reversible Immobilization of Proteins on Nylon Activated through the Formation of a Substituted Imidoester, and its Unusual Properties
}

\author{
By P. V. SUNDARAM \\ Max-Planck-Institut für Experimentelle Medizin, Abteilung Chemie, \\ D-3400 Göttingen, W. Germany
}

(Received 21 June 1979)

\begin{abstract}
Alkylation of nylon produces nylon imidate, which is used for the covalent coupling of enzymes and other proteins and ligands. Nylon imidate is unusually stable when stored wet, with a half-life of about 60 days. Reaction with enzymes has an optimum about $\mathrm{pH} 7-8$ and is extremely rapid, with about $60 \%$ of the reaction being complete in the first $10 \mathrm{~min}$. The amidine formed in reaction with an amino group can be displaced by another nucleophile. In view of this finding that nylon amidine is capable of exchanging proteins, it is now concluded that nylon-tube reactors containing immobilized enzymes made by this method may not be used as extracorporeal shunts or as on-line monitors on patients, since the enzyme in the reactor may be released into the circulation by nucleophiles in the blood. This can lead to complications. The chemistry of this displacement reaction is discussed.
\end{abstract}

The development of methods for the immobilization of catalytically active biopolymers, such as enzymes, antigens and antibodies, in the mid 1950s and early 1960s was an important milestone in biochemistry (Silman \& Katchalski, 1966). It led directly to the important technique of affinity chromatography (Lerman, 1953) and to the use of immobilized enzymes for various analytical and industrial purposes (Chang, 1977). This spurred the development of new chemical methods for coupling proteins and other ligands to insoluble polymers and to a quest for new polymers that offered a greater variety of physical and chemical properties. One such study involved the use of nylon tubes as solid polymeric supports, and a technique for coupling enzymes to the inside surface of such tubes for use in flow-through systems was first described by Sundaram \& Hornby (1970).

The original method of activating nylon for the coupling of proteins involved alkylation with dimethyl sulphate (Sundaram, 1974; Campbell et al., 1975). Later, triethyloxonium tetrafluoroborate (TTFB) was also shown to be a suitable alkylating agent (Morris et al., 1975). In our laboratory the alkylation procedure for activating nylon has been extensively used in the development of immobilizedenzyme-nylon-tube reactors (Sundaram et al., $1978 a, b$ ) for analytical purposes in clinical chemistry, food technology and environmental monitoring (P.V. Sundaram \& D. M. Munnecke, unpublished work) and in the study of the molecular mechanism of action of toxins (Sundaram \& Bermek, 1979).

The present paper deals with the properties of the nylon imidate that results from the above alkylation procedure. The unusual stability of nylon imidate and the quantitative reversibility of the nylon imidate $\rightarrow$ amidine transition are discussed in the light of the classical studies on soluble imidates by Hand \& Jencks (1962), Hunter \& Ludwig (1972), Browne \& Kent $(1975 a, b)$ and Coggins (1978).

\section{Materials and Methods}

Nylon tubing ( $1 \mathrm{~mm}$ internal diameter) was supplied by Portex Ltd., Hythe, Kent, U.K. Di $\left[{ }^{3} \mathrm{H}\right]-$ methyl sulphate (sp. radioactivity $150 \mathrm{mCi} / \mathrm{mmol}$ or $1.2 \mathrm{mCi} / \mathrm{mg}$ ) and $\mathrm{L}-\left[\mathrm{U}-{ }^{14} \mathrm{C}\right]$ lysine hydrochloride (sp. radioactivity $342 \mathrm{mCi} / \mathrm{mmol}$ ) were purchased from The Radiochemical Centre, Amersham, Bucks., U.K. Urease (type III; 28 units/mg) was obtained from Sigma Chemical Co., St. Louis, MO, U.S.A. Asparaginase (80units/mg) and lactate dehydrogenase (550units $/ \mathrm{mg}$ ) were supplied by Boehringer G.m.b.H., Mannheim, Germany.

Various buffers were used in this study, of the following compositions: phosphate buffer $\left(\mathrm{Na}_{2} \mathrm{HPO}_{4} /\right.$ $\mathrm{NaH}_{2} \mathrm{PO}_{4}, 0.1 \mathrm{M}$ ); acetate buffer (sodium acetate/ acetic acid, $0.1 \mathrm{M}$ ); citrate buffer (sodium citrate/ citric acid, $0.1 \mathrm{M}$ ); borate buffer (sodium borate/ boric acid, $0.1 \mathrm{M})$; bicarbonate buffer $\left(\mathrm{Na}_{2} \mathrm{CO}_{3} /\right.$ 
$\mathrm{NaHCO}_{3}, 0.1 \mathrm{M}$ ); phosphate/pyrophosphate buffer $\left(\mathrm{Na}_{2} \mathrm{HPO}_{4} / \mathrm{NaH}_{2} \mathrm{PO}_{4} / \mathrm{Na}_{2} \mathrm{P}_{4} \mathrm{O}_{7}, 0.1 \mathrm{M}\right)$.

\section{Alkylation procedure}

Alkylation by dimethyl sulphate was achieved by filling a $1 \mathrm{~m}$-long coiled nylon tube with the undiluted reagent. The tube was then immersed in a boilingwater bath for $4 \mathrm{~min}$ to obtain optimum activation. It was then dipped in ice-cold water to stop the reaction, washed with $30 \mathrm{ml}$ of ice-cold methanol and then $50 \mathrm{ml}$ of ice-cold water.

\section{Alkylation with di $\left[{ }^{3} \mathrm{H}\right]$ methyl sulphate}

Di $\left[{ }^{3} \mathrm{H}\right]$ methyl sulphate (sp. radioactivity $150 \mathrm{mCi} /$ $\mathrm{mmol}$ or $1.2 \mathrm{mCi} / \mathrm{mg}$ ) was diluted 8 -fold with unlabelled dimethyl sulphate, and this was used to alkylate a $1 \mathrm{~m}$-long nylon tube for $4 \mathrm{~min}$ as described above. The radioactivity left behind in the dimethyl sulphate after alkylation and the wash solution was counted. Segments of the alkylated tube were dissolved in conc. $\mathrm{HCl}$, and $0.2 \mathrm{ml}$ samples of the syrupy solution were plated on filter discs and counted for radioactivity in scintillation fluid (Aquasol; Packard). Blank tubes dissolved in $\mathrm{HCl}$ were also counted to serve as blanks.

A similar procedure was used with triethyloxonium tetrafluoroborate; in this case the reagent was used as a $0.1 \mathrm{M}$ solution in dichloromethane (available from Aldrich, Europe Division, B-2340 Beerse, Belgium); the reaction in this case was for $4 \mathrm{~min}$ at room temperature. Washing after this reaction followed exactly the same procedure as with dimethyl sulphate.

\section{Enzyme coupling}

For direct coupling of enzyme to alkylated nylon the enzyme solution was made up in a suitable buffer, and the activated tube was filled with this solution. Urease was coupled by filling the tube with a $4 \mathrm{mg} / \mathrm{ml}$ solution in pH7.0 phosphate buffer containing 1 mM-EDTA. After being kept overnight at $4^{\circ} \mathrm{C}$ the enzyme solution was removed and the tube washed with $0.1 \mathrm{M}-\mathrm{NaCl}$ followed by deionized water. Lactate dehydrogenase was coupled as a $2 \mathrm{mg} / \mathrm{ml}$ solution in the same buffer, and asparaginase as a $2 \mathrm{mg} / \mathrm{ml}$ solution in $0.1 \mathrm{M}$-borate buffer ( $\mathrm{pH} 8.0$ ).

\section{Borohydride treatment of nylon imidate and amidine}

Alkylated nylon tube, as well as tubes containing immobilized urease, were washed with $\mathrm{NaBH}_{4}$ and sodium cyanoborohydride at a concentration of $4 \mathrm{mg} / \mathrm{ml}$ in pH 4 acetate buffer, $\mathrm{pH} 6$ phosphate buffer and methanol. A typical experiment conducted in the dark consisted of the tube being filled with the solvent, to which the reducing agent was added slowly over a few minutes, during which time the borohydride solution was sucked in and squirted out several times with the help of a syringe. After the initial $20 \mathrm{~min}$ the tube, filled with solution, was left soaking in the solution for $1 \mathrm{~h}$ before being washed well with $\mathrm{pH} 7$ phosphate buffer for further testing of enzyme coupling capacity of alkylated tubes, or activity measurements in the case of urease reactors.

\section{Results and Discussion}

When the method of activation of nylon by alkylation with dimethyl sulphate was first described by Sundaram (1974) and Campbell et al. (1975) a mechanism was proposed that involved $O$-alkylation and a reactive imidate salt of nylon (Scheme 1). Further detailed study in our laboratories to characterize the reaction has revealed some rather unusual properties for the $O$-alkylated nylon.

Fig. 1 shows the kinetics of alkylation of nylon by dimethyl sulphate and triethyloxonium tetrafluoroborate. Optimum activation of the nylon tube is obtained in about $4 \mathrm{~min}$. Similar studies with triethyloxonium tetrafluoroborate were carried out by Morris et al. (1975).

When the alkylation was repeated with $\operatorname{di}\left[{ }^{3} \mathrm{H}\right]-$ methyl sulphate $(\mathrm{sp}$. radioactivity $150 \mathrm{mCi} / \mathrm{mmol}$ or $1.2 \mathrm{mCi} / \mathrm{mg}$ ) about $1-2 \%$ of the label was incorporated after $4 \mathrm{~min}$, which corresponded to about $0.5-1 \mu \mathrm{mol}$ of $O$-alkylated centres $/ \mathrm{m}$ of nylon tube.

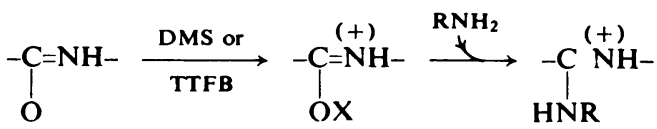

Scheme 1. Alkylation of nylon with dimethyl sulphate $(D M S)$ or triethyloxonium tetrafluoroborate (TTFB) and subsequent amidination by an amine $\mathrm{X}=\mathrm{CH}_{3}$ (DMS) or $\mathrm{C}_{2} \mathrm{H}_{5}$ (TTFB).

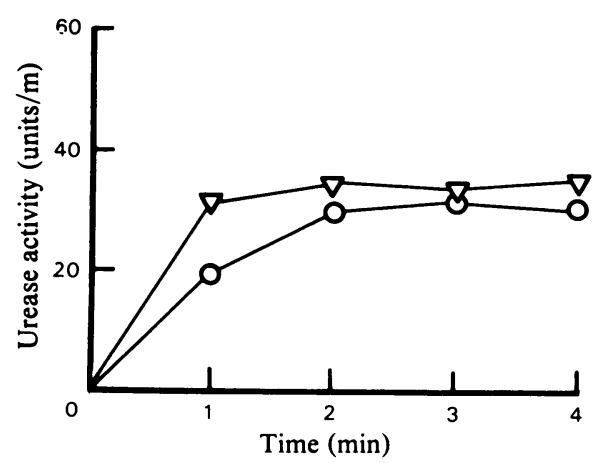

Fig. 1. Study of the kinetics of alkylation of nylon with dimethyl sulphate $(\mathrm{O})$ and triethyloxonium tetrafluoroborate $(\nabla)$

The results are expressed as the amount of urease activity coupled to the activated tubes measured under the conditions described in Table 1. 
Table 1. Storage stability' of nylon imidate The $O$-alkylated nylon tubes were stored filled with water at $4^{\circ} \mathrm{C}$ and urease was coupled to the tubes at pH $7\left(\mathrm{NaH}_{2} \mathrm{PO}_{4} / \mathrm{Na}_{2} \mathrm{HPO}_{4}, \quad 0.1 \mathrm{M}\right)$ after various lengths of time. Activities are expressed as units $/ \mathrm{m}$ of tube at $22 \pm 1{ }^{\circ} \mathrm{C}$, and the flow rate was $0.32 \mathrm{ml}$ of $0.1 \mathrm{M}$-urea in $\mathrm{pH} 7$ phosphate buffer $/ \mathrm{min}$. One unit is defined as $1 \mu \mathrm{mol}$ of substrate converted per $\mathrm{m}$ of tube at the defined flow rate and temperature.

$\begin{array}{ccc}\text { Days } & \begin{array}{c}\text { Activity } \\ \text { (units/m) }\end{array} & \begin{array}{c}\text { Percentage of } \\ \text { initial value }\end{array} \\ 0 & 19.36 & 100 \\ 9 & 18.73 & 93.6 \\ 17 & 14.92 & 76.0 \\ 25 & 14.8 & 76.0 \\ 36 & 12.22 & 63.0\end{array}$

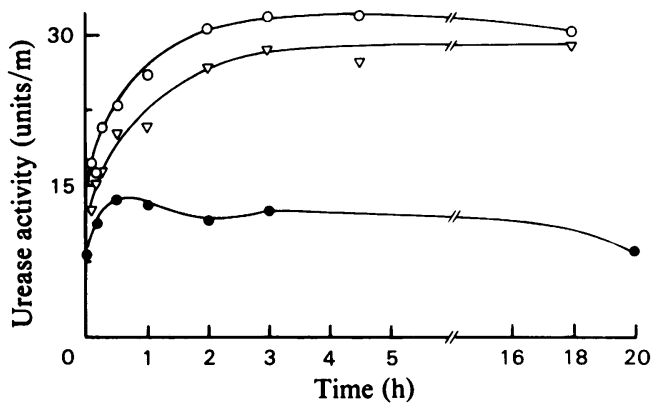

Fig. 2. Kinetics of amidine formation when nylon imidate produced by alkylation with triethyloxonium tetrafluoroborate for $4 \mathrm{~min}$ is treated with urease solution made up in pH7 phosphate buffer at $22 \pm 1^{\circ} \mathrm{C}$ and $4^{\circ} \mathrm{C}$ and $\mathrm{pH} 10$ borate buffer at $22 \pm 1^{\circ} \mathrm{C}$

Coupling in $\mathrm{pH} 7$ phosphate buffer at $22 \pm 1^{\circ} \mathrm{C}(\mathrm{O})$ and $4^{\circ} \mathrm{C}(\nabla)$. Coupling in borate buffer, $\mathrm{pH} 10$, at $22 \pm 1^{\circ} \mathrm{C}(\bullet)$.

These activated sites are available for reaction with proteins and ligands (Sundaram, 1977).

Nylon tubes alkylated by either procedure were remarkably stable when stored filled with water at $4^{\circ} \mathrm{C}$ (Table 1); after 6 weeks at $4^{\circ} \mathrm{C}$ the efficiency at coupling enzymes had decreased by only $37 \%$. Extrapolating this value, it may be concluded that the half-life of nylon imidate is around 50-60 days. This is in marked contrast with the soluble imidates, which are known to be extremely labile when exposed to moisture and which have half-lives in aqueous solution that have been estimated to be a few minutes or, at most, as was re-evaluated by Coggins (1978), a few tenths of a minute.

Perfusion of the dimethyl sulphate-activated tube for $1 \mathrm{~h}$ at $22^{\circ} \mathrm{C}$ with a pH4 citrate buffer in one case and a pH 10 borate buffer in another before attempting to couple urease led to losses in coupling efficiency of 9 and $19 \%$ respectively. This is a little different from what we know of simple soluble imidates, which are hydrolysed more rapidly at acid pH values (Roger \& Nielson, 1961).

Reaction of nylon imidate with enzyme is very rapid, over $60 \%$ of the maximum observed substitution occurring within the initial $10 \mathrm{~min}$. Results of coupling urease at $\mathrm{pH} 7$ and $\mathrm{pH} 10$ and at 4 and $22^{\circ} \mathrm{C}$ (Fig. 2) showed that substitution is close to its maximum after $3 \mathrm{~h}$ at $22^{\circ} \mathrm{C}$. Also, coupling proceeds faster at $\mathrm{pH} 10$, even though the specific activity of the nylon tube-supported urease was only $40 \%$ of the activity of the enzyme immobilized at $\mathrm{pH} 7$.

The $\mathrm{pH}$-dependence of coupling of urease (Fig. 3) with two buffer systems shows that optimum yields are obtained between $\mathrm{pH} 7$ and 8. A dramatic effect of buffer ions on coupling efficiency may also be noticed (compare also with the activity of a tube coupled at $\mathrm{pH} 10$ with borate buffer in Fig. 2).

A similar coupling experiment with lactate dehydrogenase in phosphate/pyrophosphate buffer showed that coupling yield increased as the $\mathrm{pH}$ increased from 7 to 10 , although the specific activity of the immobilized enzyme decreased with $\mathrm{pH}$. In these coupling experiments with urease and lactate dehydrogenase the enzyme was left in contact with the activated tube for $18 \mathrm{~h}$ at $4^{\circ} \mathrm{C}$. Because of this long reaction time the effect of $\mathrm{pH}$ on the stability of both the enzyme and the nylon imidate influence the coupling yield and the specific activities of the final products.

In the coupling reactions of proteins, the unprotonated amino groups of lysine residues are presumably the reactive species. Their cencentration increases with increasing $\mathrm{pH}$, whereas the concentration of the protonated form of the imidate, which is the

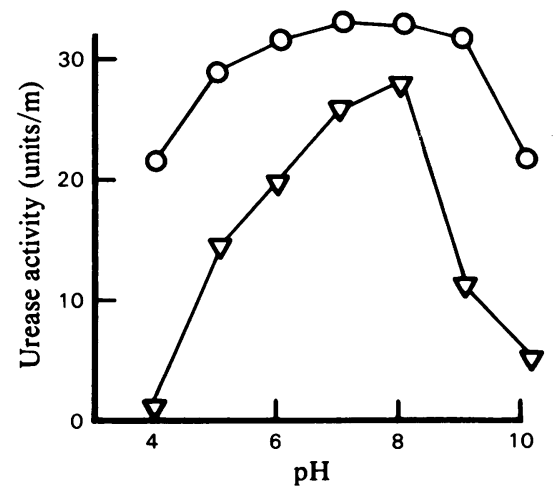

Fig. 3. Effect of $p H$ and buffer ion on coupling efficiency (as reflected by final activity) of urease to nylon tube alkylated with dimethyl sulphate

0 , Phosphate/pyrophosphate buffer; $\nabla$, pH4-6 citrate, $\mathrm{pH} 7$ phosphate and $\mathrm{pH} 8-10$ borate buffers. 
reactive form of the nylon tube, decreases with increasing pH (Hand \& Jencks, 1962).

Nylon tubes alkylated with dimethyl sulphate and triethyloxonium tetrafluoroborate coupled 3.1 and $4.5 \%$ respectively of $\mathrm{L}-\left[\mathrm{U}-{ }^{14} \mathrm{C}\right]$ lysine (sp. radioactivity $342 \mathrm{mCi} / \mathrm{mmol}$ ) to $1 \mathrm{~m}$ of tube at $\mathrm{pH} 7$, which corresponds to 0.242 and $0.355 \mu \mathrm{mol}$ of lysine attached $/ \mathrm{m}$. A similar tube will couple about $1-2 \mathrm{mg}$ of a high-molecular-weight protein, such as urease (mol.wt.480000), which is about $2-4 \mathrm{nmol}$ of the protein. Both the size of the enzyme molecule and the number of available lysine groups influence the coupling yield. Aliphatic imidoesters are reported to have $\mathrm{p} K_{\mathrm{a}}$ values of about 6-8 (Streuli, 1959), and, in this context, it would be valuable to know the $\mathrm{p} K_{\mathrm{a}}$ of nylon imidate. However, efforts to ascertain its ionization constant by titration did not give a clear result.

\section{Nucleophile exchange on the amidine carbon}

Both the activated nylon (nylon imidate) and the enzymes immobilized on nylon (nylon amidine) are very stable in the absence of nucleophiles. However, the immobilized enzymes underwent a facile exchange reaction in the presence of nucleophiles. To study this further nylon-tube-supported urease was subjected to a series of washing experiments with solutions of various small nucleophiles, such as $\mathrm{Cl}^{-}$ $\left(\mathrm{NaCl}\right.$ and $\mathrm{NH}_{4} \mathrm{Cl}$ ), $-\mathrm{NH}_{2}$ (ethanolamine), $\mathrm{HCO}_{3}{ }^{-}$ $\left(\mathrm{NaHCO}_{3}\right)$ and $\mathrm{SCN}^{-}(\mathrm{KSCN})$, at $\mathrm{pH} 7,8$ and 9.4, and solutions of lactate dehydrogenase in $\mathrm{pH} 7$ phosphate buffer and asparaginase in $\mathrm{pH} 8$ borate buffer.

The notable finding from these washing experiments was that an enzyme that had initially reacted with the nylon imidate to form an amidine could be displaced by another incoming small nucleophile or another enzyme. Smaller nucleophiles were better than enzymes in displacing the first enzyme; this is presumably a steric effect. Among the smaller nucleophiles, $\mathrm{SCN}^{-}$was the most efficient; higher concentrations of the nucleophiles and alkaline $\mathrm{pH}$ values accelarated the exchange reaction.

After the urease had been displaced from the tube with a small nucleophile, the tube could be reconstituted back to almost $100 \%$ activity by refilling it with the enzyme solution, or a second enzyme, such as lactate dehydrogenase or asparaginase, could be coupled. These enzymes were chosen because of their similar isoelectric points (both are between 5.0 and 5.5). Also a tube displaying both enzyme activities could be obtained by partial displacement of urease with a small nucleophile and then treatment with a second enzyme or by direct washing of the urease-tube with the second enzyme. Figs. 4 and 5 show the effects of washing with these small and large nucleophiles.

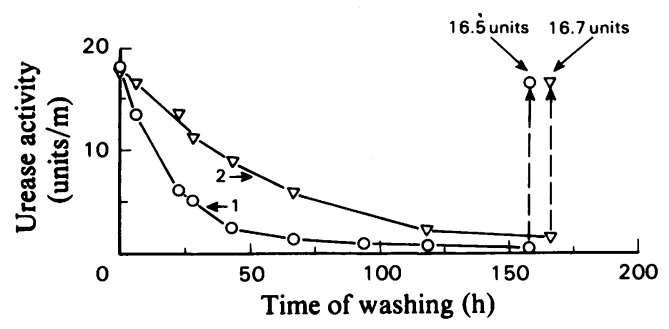

Fig. 4. Results of washing nylon tubes containing immobilized urease with $\mathrm{NaHCO}_{3}$ and $\mathrm{KSCN}$

At every stage, activities of urease-tubes were tested under the conditions described in Table 1. Expt. 1: washed at $0.15 \mathrm{ml} / \mathrm{min}$ with $0.1 \mathrm{M}-\mathrm{NaHCO}_{3}, \mathrm{pH} 8$, $+1 \mathrm{~mm}$-EDTA $(\nabla)$. Expt. 2: washed at $0.19 \mathrm{ml} / \mathrm{min}$ with $0.1 \mathrm{M}-\mathrm{KSCN}$ in $\mathrm{pH} 7$ phosphate buffer $+1 \mathrm{~mm}$ EDTA (O). The broken arrows indicate the reconstitution of urease activity when the tubes were refilled with urease solution.

In Fig. 4 effects of washing with $0.1 \mathrm{M}-\mathrm{NaHCO}_{3}$ (pH 8.0) and 0.1 M-KSCN (Expts. 1 and 2) are shown. Both tubes when refilled with urease solution as in the original coupling, were reconstituted to 90.6 and $96 \%$ of the original activity displayed before washing.

Similarly, washing for about $15 \mathrm{~h}$ with $1 \mathrm{M}-\mathrm{NaCl}$ (Fig. 5, Expt. 3) followed by $6 \mathrm{M}-\mathrm{NaCl}$ for about $30 \mathrm{~h}$ completely removed almost all urease activity. This salt-washed tube was reconstituted to $84.5 \%$ of its original activity (that is to 17.97 units) after being filled with urease for $15 \mathrm{~h}$. The same tube was again washed, first with $15 \mu \mathrm{M}-\mathrm{KSCN}$ ( $\mathrm{O}_{---0}$ ) in $\mathrm{pH} 7$ phosphate buffer (comparable with a $2 \mathrm{mg} / \mathrm{ml}$ lactate dehydrogenase concentration) followed by $0.1 \mathrm{M}$ $\mathrm{KSCN}$ for $87 \mathrm{~h}$ ( $0-0$ ). By this time almost all of the urease activity had been removed. Once again urease activity could be restored to $100 \%$ of its former activity by resoaking the tube in enzyme solution.

Washing a freshly made urease-tube (19.73 units $/ \mathrm{m}$ ) with a $2 \mathrm{mg} / \mathrm{ml}$ lactate dehydrogenase solution in $\mathrm{pH} 7$ phosphate buffer (Fig. 5, Expt. 4) for $26.5 \mathrm{~h}$ removed 2.1 units or $11.2 \%$, of urease activity and 0.251 unit of lactate dehydrogenase became attached to the tube in its place. Resoaking the tube with a $2 \mathrm{mg} / \mathrm{ml}$ urease solution at $\mathrm{pH} 7$ for $6 \mathrm{~h}$ raised the urease activity to 35.6 units with a simultaneous loss of lactate dehydrogenase activity. When this tube was again kept in contact with the urease solution for 5 days at $4^{\circ} \mathrm{C}$ the activity stabilized at 39.52 units $/ \mathrm{m}$. This could again be removed by washing with $0.1 \mathrm{M}-\mathrm{NH}_{4} \mathrm{Cl}$ and $0.1 \mathrm{M}-\mathrm{KSCN}$ and the tube reconstituted back to 12.7 units/m (Fig. 5).

A similar washing of a freshly made urease-tube with $2 \mathrm{mg}$ of asparaginase $/ \mathrm{ml}$ in $\mathrm{pH} 8$ borate buffer removed 4 units of urease in $18 \mathrm{~h}$, and 1.27 units of asparaginase was coupled in its place. 


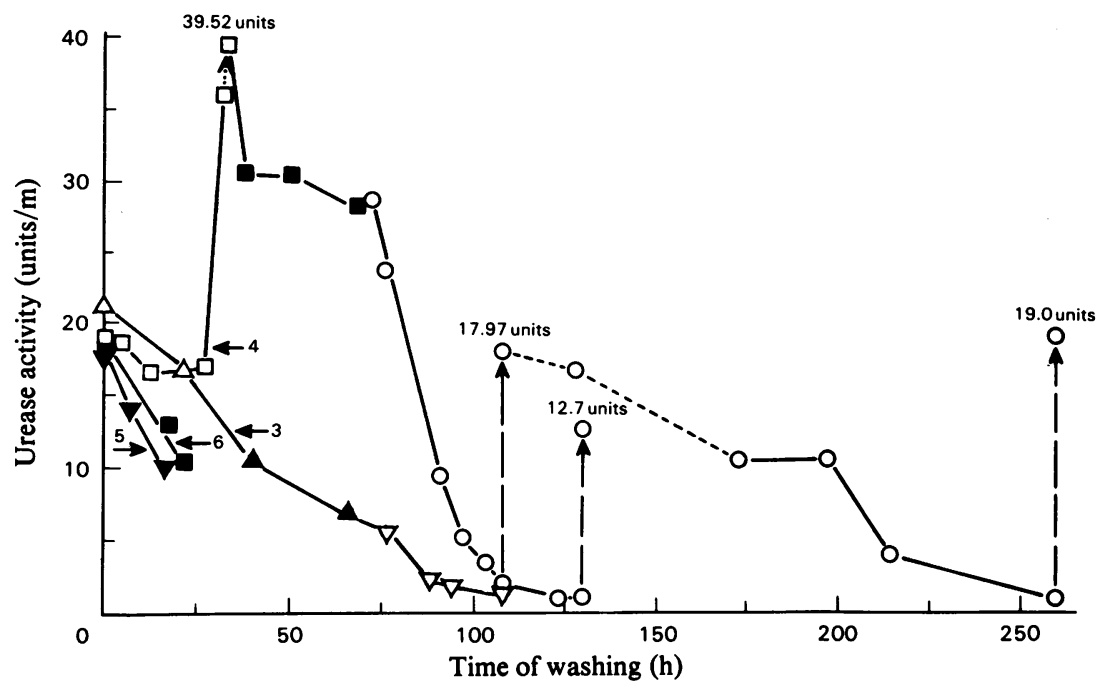

Fig. 5. Results of washing nylon tubes containing immobilized urease with small nucleophiles $\mathrm{Cl}^{-}, \mathrm{SCN}^{-},-\mathrm{NH}_{2}$ and an enzyme

Expt. 3: washed at $0.25 \mathrm{ml} / \mathrm{min}$ with $0.1 \mathrm{M}$-urea $+1 \mathrm{M}-\mathrm{NaCl}(\Delta)$, then with $1 \mathrm{M}-\mathrm{NaCl}(\Delta)$, followed by $6 \mathrm{M}-\mathrm{NaCl}(\nabla)$ at $0.15 \mathrm{ml} / \mathrm{min}$. The tube was then reconstituted with urease, then washed with $15 \mu \mathrm{M}-\mathrm{KSCN}(\mathrm{O}---\mathrm{O})$ in $\mathrm{pH} 7 \mathrm{phos}-$ phate buffer, followed by $0.1 \mathrm{M}-\mathrm{KSCN}(\mathrm{O}-\mathrm{O})$. Expt. 4: washed with $2 \mathrm{mg}$ of lactate dehydrogenase/ml, $\mathrm{pH} 7$, at $0.3 \mathrm{ml} / \mathrm{min}(\square)$, tube reconstituted with urease for 5 days $(-\rightarrow)$, then washed with $0.1 \mathrm{M}-\mathrm{NH}_{4} \mathrm{Cl}$ at $22^{\circ} \mathrm{C}(\square)$, followed by washing at $0.12 \mathrm{ml} / \mathrm{min}$ with $0.1 \mathrm{M}-\mathrm{KSCN}$ at $22^{\circ} \mathrm{C}(\mathrm{C})$. Expt. 5: washed with $0.1 \mathrm{M}$-ethanolamine ( $\left.\nabla\right)$. Expt. 6: washed with $0.1 \mathrm{M}-\mathrm{NH}_{4} \mathrm{Cl}(\mathbf{\square})$.

Expts. 5 and 6 (Fig. 5) show effects of washing freshly made urease-tubes with $0.1 \mathrm{M}$-ethanolamine and $0.1 \mathrm{M}-\mathrm{NH}_{4} \mathrm{Cl}$ respectively.

'Chasing' an enzyme off the nylon with a small nucleophile was much easier than with the large enzyme molecules, since presumably a larger molecule may be attached to the nylon at several points and is therefore more easily exchanged by several small molecules attacking in concert at all of the attachment points. Consistent with this finding, it was also found in an experiment with $\left[{ }^{14} \mathrm{C}\right]$ lysine that this small molecule exchanged more easily on the activated nylon, which implied that a small molecule attached at a single point does not yield a stable product. Similar results were obtained in an independent study, when nucleotides and cofactors were coupled to nylon imidate (Sundaram, 1978).

The reconstitution was a time-dependent process similar to the original coupling, and the yield of immobilized-enzyme activity was also dependent upon the pH. These results emphasize that the secondary couplings of enzyme to the nylon imidate follow a similar mechanism to the primary couplings.

\section{Borohydride reduction of the charge on the amide nitrogen of nylon imidate}

An attempt to reduce the positive charge on the amide nitrogen of the alkylated nylon with $\mathrm{NaBH}_{4}$ or sodium cyanoborohydride with a view to stabil- izing the amidine structure was not successful. Reductions were tried with both the reagents, each in $0.1 \mathrm{M}$-acetate buffer, $\mathrm{pH} 4,0.1 \mathrm{M}$-phosphate buffer, pH6, and in methanol. Freshly made nylon imidate, treated first in this manner, still reacted with enzyme with no decrease in the activity of the final product. When immobilized urease was subjected to this treatment, the enzyme was slightly inactivated in the case of the pH4 and 6 treatments, and the methanol medium completely abolished its activity. However, the enzyme could still be exchanged for fresh enzyme of full activity.

In the use of nylon-tube-supported urease or uricase in routine clinical analysis (Sundaram et al., $1978 a, b)$, operational stability studies had shown that about $50-60 \%$ of activity was lost after several thousand tests, taking place over the course of several weeks. It had been assumed that this was due to a slow decay in the activity of the enzyme. However, it was found that these reactors, even after such long use in the clinic, regained part or most of their activity when refilled with enzyme solution and could then be used again. An important consequence of the above findings is that reactors made by the above method may not be used as on-line monitors (Noy et al., 1978) or in extracorporal shunts on patients, since nucleophiles in blood could release the enzyme into the circulation, an event that is self-defeating and potentially dangerous to the patient. 

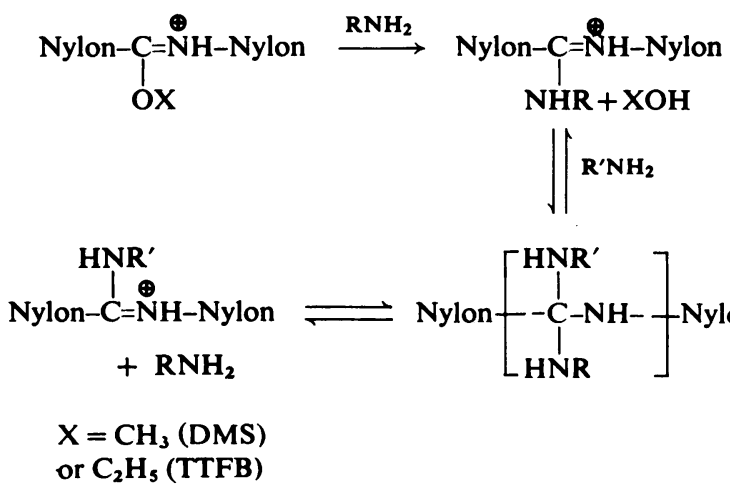

Scheme 2. Sequence of events following amidination of nylon imidate and a subsequent transamidination reaction $\mathrm{X}=\mathrm{CH}_{3}$ (dimethyl sulphate) or $\mathrm{C}_{2} \mathrm{H}_{5}$ (triethyloxonium tetrafluoroborate).

\section{A possible mechanism of the nylon imidate $\rightarrow$ amidine reaction}

The above experiments present the picture of nylon imidate as a rather unusual molecule; it is exceptionally stable compared with soluble imidates, but after conversion to nylon amidine by reaction with amino groups it can undergo very facile reversible transamidination reactions. A possible explanation of our observed data is presented in Scheme 2, although this is by no means the only plausible mechanism and more detailed chemical studies will be required to elucidate this.

The facile exchange reaction is thus believed to be a transamidination reaction (Coggins, 1978), and, once amidine formation has occurred, transamidination can occur many times over. The alternative mechanism of exchange involving $\mathrm{N}$-alkylimidate formation (Browne \& Kent, 1975a,b; Coggins, 1978) seems intrinsically less likely for a structured polymer like nylon, especially when the incoming nucleophile is a protein. In the case of washing with another nucleophile such as $\mathrm{Cl}^{-}$, a chloroimidate could be formed by elimination of the enzyme, and this chloroimidate itself would be as reactive as the originally alkylated species, nylon imidate.

Of interest is the ability of the nylon tube to retain two different enzyme activities when the tube carrying urease activity is washed with a second enzyme such as lactate dehydrogenase (Expt. 4, Fig. 5) or asparaginase. The fact that only $2-4 \mathrm{nmol}$ of urease $/ \mathrm{m}$ of tube are bound, whereas alkylation of $0.5-1 \mu \mathrm{mol} / \mathrm{m}$ occurs implies that both enzymes could bind to different sites. However, since it is also seen that the urease activity is doubled (Expt. 4, Fig. 5) after the original tube is washed with lactate dehydrogenase followed by urease again, a tetrahedral intermediate (Scheme 2, R and $R^{\prime}$ ) in which two enzyme molecules are bound to the same carbon must be considered.
The great stability of nylon imidate is almost certainly due to the fact that simple hydrolysis of the imidate group to an ester group is prevented by the tight structure of the polymer. The imidate nitrogen atom cannot leave because it is part of the polymer. The only group that can leave readily is the $\mathrm{OX}^{-}$ group, and it is this group that can be readily displaced by incoming nucleophiles such as an $-\mathrm{NH}_{2}$ group, $\mathrm{Cl}^{-}, \mathrm{HCO}_{3}{ }^{-}$and $\mathrm{SCN}^{-}$. Existing data do not permit further speculation about the mechanism by which these individual nucleophiles operate.

This project was supported by a grant by D.F.V.L.R. (Deutsche Forschungs- und Versuchs-anstalt für Luft-und Raum-fahrt). I gratefully acknowledge the technical assistance of Mrs. R. Wassermann. I also thank Dr. S. M. Hecht, Department of Chemistry, M.I.T., Cambridge, MA, U.S.A.) for helpful discussions and Dr. J. R. Coggins (Department of Biochemistry, University of Glasgow, Glasgow, Scotland, U.K.) for a critical reading of the manuscript.

\section{References}

Browne, D. T. \& Kent, S. B. H. (1975a) Biochem. Biophys. Res. Commun. 67, 126-132

Browne, D. T. \& Kent, S. B. H. (1975b) Biochem. Biophys. Res. Commun. 67, 133-138

Campbell, J., Hornby, W. E. \& Morris, D. L. (1975) Biochim Biophys. Acta 384, 307-316

Chang, T. M. S. (ed.) (1977) Biomedical Applications of Immobilized Enzymes and Proteins, vols. 1 and 2, Plenum Press, New York

Coggins J. R. (1978) in Theory and Practice in Affinity Techniques (Sundaram P. V. \& Eckstein, F., eds.), pp.89-112, Academic Press, London and New York

Hand, E. S. \& Jencks, W. P. (1962) J. Am. Chem. Soc. 84, 3505-3514

Hunter, M. J. \& Ludwig, M. L. (1972) J. Am. Chem. Soc. 84, 3491-3504 
Lerman, L. S. (1953) Proc. Natl. Acad. Sci. U.S.A. 39, 232-236

Morris, D. L., Campbell, J. \& Hornby, W. E. (1975) Biochem. J. 147, 593-603

Noy, G. A., Brockle, A. L. J. \& Alberti, K. G. M. M. (1978) Clin. Chim. Acta 89, 135-144

Roger, R. \& Nielson, D. G. (1961) Chem. Res. 61, 179-211

Silman, I. H. \& Katchalski, E. (1966) Annu. Rev. Biochem. 66, 873-908

Streuli, C. A. (1959) Anal. Chem. 31, 1651-1654

Sundaram, P. V. (1974) Nucleic Acids Res. 1, 1587-1599

Sundaram, P. V. (1977) in Biomedical Applications of Immobilized Enzymes and Proteins (Chang, T. M. S., ed.), vol. 1, p. 317-340, Plenum Press, New York
Sundaram, P. V. (1978) in Theory and Practice in Affinity Techniques (Sundaram, P. V. \& Eckstein, F., eds.), pp. 77-87, Academic Press, London and New York Sundaram, P. V. \& Bermek, E. J. (1979) Solid-Phase Biochem. in the press

Sundaram, P. V. \& Hornby, W. E. (1970) FEBS Lett. 10, 325-329

Sundaram, P. V., Igloi, M. P., Wassermann, R., Hinsch, W. \& Knoke, K.-J. (1978a) Clin. Chent. (WinstonSalem, N.C.) 24, 234-239

Sundaram, P. V., Igloi, M. P., Wassermann, R. \& Hinsch, W. (1978b) Clin. Chem. (Winston-Salem, N.C.) 24, 1813-1817 